\title{
EESTI FILOLOOGIA SÜND JA KIRIKULAULUDE TÕLKED
}

\author{
KRISTIINA ROSS
}

$\mathrm{F}$ iloloogia keskmeks on keel. Iga rahvusliku filoloogia eelduseks on vastava rahvakeele ning selles loodud rahvaluule ja kirjanduse olemasolu. ${ }^{1}$ Rahvusliku filoloogia sünnist saab rääkida siis, kui on tekkinud kõiki kolme valdkonda uuriv teadus. Miskeelne see teadus olema peab, ei ole filoloogia määratlusega kuidagi piiratud. Eesti filoloogia tekke üle arutlemisel osutub metakeele küsimus siiski oluliseks ning paistab olevat otstarbekas eristada filoloogia välis- ja sisevaadet. Välisvaade oleks niisuguse jaotuse korral mingi keele ning selles loodud kirjanduse ja rahvaluule uurimine ja kirjeldamine mõnes teises metakeeles, sisevaade keele ja tema tekstide uurimine ja kirjeldamine selles keeles endas. Suure osa Euroopa rahvuslike filoloogiate tekkevõi eellugu on olnud välisvaateline, kuivõrd kuni XVII sajandi lõpuni oli kõigi uuritavate nähtuste kirjelduskeeleks enamasti ladina keel. Eesti filoloogia eripäraks võib pidada vaid seda, et pärast ladina keele taandumist ei saanud kirjelduskeeleks mitte eesti keel ise, vaid saksa keel ning saksakeelne välisvaade kestis üsna kaua. ${ }^{2}$

Eesti filoloogia välisvaade tekkis saksa teoloogia kohapealse praktilise väljundina. Luterlikel pastoritel oli vaja eesti keeles jumalateenistust pidada ja hingi hooldada ning selleks oli tarvis ära õppida eesti keel. Sellest praktilisest vajadusest sündis esimene eesti keele kirjeldus, Heinrich Stahli „Anführung zu der Esthnischen Sprach” („Sissejuhatus eesti keelde”, 1637). Nagu kõigi pikaajaliste protsessidega kipub olema, võib ka eesti filoloogia teket muidugi siduda hoopis mõne muu XVII sajandi konkreetse teose või autoriga, näiteks Johannes Gutslaffi ja tema töödega. Nii või teisiti, päriselt õide puhkes välisvaateline eesti filoloogia alles XIX sajandil, eriti Beiträge'des. Võib-olla ongi Beiträge'de 20 numbrit (1813-1832) välisvaatelise eesti filoloogia tippsaavutus, ehkki hilisemast ajast kuuluvad suurteoste hulka kindlasti veel vähemalt F. J. Wiedemanni grammatika ja sõnaraamat.

Kogu saksakeelne eesti filoloogia ei vastanud siiski rahvusliku filoloogia ühele nõudele: see ei hõlmanud eestikeelse ilukirjanduse käsitlusi. Ilukirjanduse eiramise põhjuseks oli eeskätt asjaolu, et eestikeelset ilukirjandust veel sama hästi kui polnudki. Kuid asjal oli ka sisulisem külg. Nii kaasati Kreutzwaldi „Kalevipoeg” sajandi keskel küll saksakeelsesse diskussiooni, aga

\footnotetext{
${ }^{1}$ Vähemasti selles tähenduses, nagu mis tahes rahvuslikku filoloogiat eesti traditsioonis saksa ja vene eeskujul on mõistetud, vt nt ENE 1970: 320: „...nüüdisajal kasut. terminit „f.” eeskätt keele-, kirjandus- ja rahvaluuleteaduse kompleksnimetusena.”

${ }^{2}$ Sellestki aspektist ei ole eesti filoloogia muidugi unikaalne: ladina keele taandumisel arenesid välisvaatelisena näiteks ka meie naaberfiloloogiad: soome filoloogia rootsikeelsena ja läti filoloogia saksakeelsena. Siiski tekkis eesti sisevaateline filoloogia soome omast hiljem ja ka läti kultuuriga võrreldes on Eesti olnud oma välisvaatelises filoloogilises käsitluses tugevamini eksotiseeritud (Plath 2008).
} 
saksakeelset eesti filoloogiat huvitas see eeskätt kui rahvaluule näide, mitte kui tärkava rahvuskirjanduse võimalik nurgakivi.

Eesti filoloogia sisevaade sai sündida ainult koos eestikeelse ilukirjandusega või vähemalt koos selle võimalikkuse tunnistamisega. Ka eestikeelsele ilukirjandusele ning selle üle peetavale eestikeelsele diskussioonile võib välja pakkuda mitu alguspunkti. Sisevaate sünniajaks võib kuulutada Kristian Jaak Petersoni luule ja päevaraamatu. Või pigem siiski mõne XIX sajandi teise poole sündmuse, näiteks Koidula ja Kreutzwaldi kirjavahetuse (18671873), Sakala ja Oleviku eestikeelse kirjanduskriitika (1878-1880-ndad), Karl August Hermanni esimese eestikeelse eesti keele grammatika (1884) vms tähise. Igal juhul oli ilukirjanduse sünni ja eestikeelse kirjanduskriitilise arutluse tekke eelduseks eesti kirjakeele jõudmine vajalikku faasi. Ühelt poolt pidi see autorite vajadusi mööda suutma vahendada ja kirjeldada lisaks õpetuslikule ivale ka puhtalt poeetilisi taotlusi, teisalt pidi see olema arusaadav ja jõukohane piisavalt suurele osale eestikeelsetest lugejatest.

Järgnevas püütaksegi visandada, kuidas niisugune kirjakeele variant kujunes ja missugune osa oli selles protsessis lauluraamatutel laiemalt ning eriti pietistlikul lauluraamatul.

\section{Varased tõlked}

Kirjalik eesti keel hakkas kujunema XVI sajandil luterlike, valdavalt saksa emakeelega pastorite tõlketegevuse viljana. Esialgu tõlgiti katekismusi, kirikulaule ja perikoope (ehk jumalateenistusel etteloetavaid piiblikatkendeid). Tõlked olid mõeldud abivahendiks eestikeelse jumalateenistuse läbiviimisel neile pastoritele, kes ise piisavalt hästi eesti keelt ei osanud. Kui palju sellest sakslaste loodud ja vahendatud tekstist eestikeelse kogukonna keeleteadvusse jõudis, on raske hinnata. Lihtsamad palvevormelid ja muud kristliku algõpetuse väljendid olid eesti keelde imbunud juba katoliku ajal ja nende juurdumine muidugi jätkus. Kuid luteri kiriku kahe põhilise suure kirjandusliigi, piibli ja kirikulaulu keele mõju varaprotestantlikul ajal on tagantjärele keeruline kindlaks teha. Võib ainult oletada, et kirikus etteloetud piiblitõlkekatkendid, mis esialgu olid pealegi üsna puises ja paiguti vigases eesti keeles, läksid koguduseliikmetel ühest kõrvast sisse, teisest välja. Pigem võisid (pool)kirjaoskamatule eestlasele algusest peale lähemale jõuda kirikulaulude vahendatud sõnumid. Erinevalt muust tekstist, mida ainult kuuldi, tuli kirikulaule kaasa laulda, mis juba iseenesest sundis nende sisu teadvustama. Pealegi on kirikulaul üldjuhul lihtsakoelisem tekst kui piibel. Ka saksakeelne koguduselaul oli alguses mõeldud just lihtrahvale, ehkki XVII sajandil sugenes lauluvarasse ka keerulisemat ja sügavamat vaimulikku luulet. Võib arvata, et eesti kogukonna keelelist teadvust on kirikulaulud mõjutanud palju olulisemal määral kui muud vaimulikud tekstitüübid (vt lähemalt Ross 2016a).

Kuni XVII sajandi esimese pooleni laulude ja piiblitõlke (tol ajal veel õieti ainult perikoobitõlgete) keelelistes taotlustes mingit vahet polnudki, sest laule tõlgiti nagu tavalist proosateksti, värsivormilistele ja prosoodilistele piirangutele tähelepanu pööramata. Tolleaegsele tõlketraditsioonile on üldiselt omane saksa originaali sõnasõnaline ülekandmine, kusjuures enamasti 
püütakse tõlkida lausa morfeemilise täpsusega. Martin Lutheri tõlkealaste taotlustega, kes nõudis, et piiblitõlke keel peab olema lihtrahvale arusaadav ning vajadusel tuleb teksti ümber sõnastada, kui see oletatavale lugejale muud moodi mõistetav pole (vt Luther 2000 [1530]), ei saa valdavat osa varasemast säilinud eestikeelsest tekstist kuidagi seostada. Või kui, siis ainult mööndes, et nende vahetuks sihtgrupiks ei olnudki mitte eesti kogukond, vaid viletsama keeleoskusega saksa pastorid, kellel oligi võimalikult saksapärasest tõlkest kergem aru saada.

Eesti koguduse positsioonilt vaadatuna on need tõlked kohmakad ja tekstide sisugi on raske hoomata. Kirikuraamatute eessõnadest võib küll leida kaudseid andmeid praeguseks kaduma läinud laulutõlgete kohta, mis olla olnud paremad kui XVII sajandi alguse tõlked. Näiteks sajandi keskpaiga esimese värsistatud lauluraamatu eessõnas öeldakse, et veidi aega tagasi olla keegi jesuiit andnud trükki üsna häid laulude värsstõlkeid (Salemann jt 1656: [25]). XVII sajandi lõpus mainitakse XVI sajandi keskpaigas ilmunud Johann Schnelli laulutõlkeid, mida vanemad talupojad senimaani laulvat (Virginius 1983 [1691]: 137). Nende viidete najal on oletatud, et kunstiline värsstõlge võis eesti keeles rakendamist leida juba enne XVII sajandi keskpaika (Neithal 2005). Paraku on kõik säilinud varasemad laulutekstid, mis leiduvad Georg Mülleri jutlustes, Heinrich Stahli lauluraamatus ning Joachim Rossihniuse käsiraamatu käsikirjalises lisas, proosatõlkelised. Enamasti on tegu saksa originaali kohmaka sõnasõnalise ümberpanekuga. Nii nagu Stahli avaldatud perikoobitõlgetes, võib ka tema lauluraamatus siiski paiguti kohata vabamat fraseoloogilist tõlget. See toetab oletusi, et Stahl ei tõlkinud oma avaldatud tekste ise, vaid pigem koondas kokku kõik seni tõlgitu (vt lähemalt Habicht 2001: 18-40), sest igatahes pidi mõni laulude tõlkija eesti keelt piisavalt hästi tundma, julgemaks saksa teksti sõnastusest eemalduda. Näiteks Martin Lutheri kirikulaulu „Ein feste Burg ist unser Gott” esimeses salmis võib Stahli tõlkeversioonis esile tuua koguni kaks värssi, milles pole sõnasõnalist tõlkemeetodit järgitud. Nii on esimese salmi teise värsi tõlkes lisatud atribuut terav: ein gute Wehr und Waffen > üx heh terraw möck ninck kilp; 6. värsis aga tõlgitud täiesti ümberütlevalt: mit ernst ers jetzt meynt > weggiwast temma ommat asjat hajap (Lauluraamat 1637: 137). Seesugused vabama tõlke näited kinnitavad, et vähemalt mingi osa varasest tõlkest oli suunatud otse eestlasest kuulajale või lugejale ning püüdis olla tema jaoks võimalikult arusaadav. Mingeid vormilise värsstõlke või poeetilise sõnastuse taotlusi pole varastes tõlgetes seni õnnestunud tuvastada. Ka teksti sisulise arusaadavuse huve teenivaid keelelisi mugandusi on säilinud laulutekstides tegelikult vähe, nii et lisaks rütmilisele konarusele on need enamasti ka sisuliselt sama raskesti jälgitavad nagu tollane keskmine proosatõlge.

\section{Barokktõlge}

Esimene eestikeelne selgelt poeetiliste taotlustega kirjalik tekst oli Reiner Brockmanni „Carmen Alexandrinum Esthonicum” 1637. aastal. Juhuluule viljelemist ajendas vormiesteetiline püüdlus „talitseda ühe keele silbid ja sõnad lauluks, et ülistada kunste ja õppida tundma Jumala loometööd” (Lepajõe 2009: 771). Siinses käsitluses võib kogu barokset juhuluulet vaadelda 
eeltreeninguna eesti keele arendamisel ilukirjanduse keeleks. Paraku jättis juhuluule eestikeelse lugeja või kuulaja praktiliselt täiesti mängust välja. See oli kohaliku, peamiselt saksa emakeelega vaimueliidi siseasi. Eestikeelsele publikule märksa lähemale jõudsid juhuluulega samast, vormilist ilu taotlevast ideaalist virgutust saanud kirikulaulude tõlked. Nagu teada ilmusid esimesed säilinud eestikeelsed kirikulaulude värsstõlked 1656. aasta lauluraamatus. Tõlkijateks olid lisaks sellelesamale Reiner Brockmannile veel Georg Salemann, Martin Gilläus ja Heinrich Göseken ning tõlkimist alustati tõenäoliselt juba 1630. aastate lõpul, mil Tallinnas puhkes seoses Paul Flemingi siinviibimisega õide luuleharrastus. Nagu juhuluules, nii lähtuti ka kirikulaulude tõlkimisel Martin Opitzi 1624. aastal ilmunud raamatu „Buch von der Deutschen Poetery" arusaamadest, mida püüti võimalikult järjekindlalt rakendada. Seetõttu kasutati tõlkes vahelduvat silbilisrõhulist värsimõõtu palju rangemini, kui seda varasemates, Opitzi-eelsetes saksa originaalluuletustes oli tehtud. Riimiskeemides kopeeriti originaaltekstide skeeme. Tõlkijad olid oma saavutuse üle ise äärmiselt uhked ja veendunud, et selle teoga on nad tõstnud eestlased kultuurrahvaste hulka (Masing, Soosaar 1999 [1956]: 75-77). Nad rõhutavad eessõnas, et ehkki nende tõlge pole veel täiuslik, on see mõnes mõttes saksa originaalidest paremgi, sest selles on välditud paljusid saksa laulude konarusi, kus ,jambid ja trohheused sageli kokku on segatud” (Salemann jt 1656: [30-31]). Siiski ei saa väita, et tõlkes oleks keskendutud ainult välisele vormitäiusele. Arvatavasti on püütud jälgida sedagi, et riim aitaks esile tuua sisulisi võtmesõnu ning riimipositsiooni ei sattuks üksnes tühjad täitesõnad. Nii on riimi sunnil loodud lausa uusi sõnu, nagu tegusõnavormi on riimiks leiutatud kuradi sünonüüm põrgukonn (vt lähemalt Ross 2013). Väärib tähelepanu, et tõlkijad on suutnud ka originaali kujundeid vormiliselt adekvaatse luuletõlke kohta üllatavalt väikeste kadudega edasi anda. Parimates eestindustes on neil õnnestunud koguni rakendada eesti keele pakutavaid erivõimalusi nii, et tõlge on lisaks värsitehnilisele ladususele kujundlikult ja keeleliselt originaalist rikkamgi, nagu tohib ehk väita näiteks Martin Lutheri laulu „Ach Gott vom Himmel sieh darein” teise salmi teise poole kohta, mille eestinduses Reiner Brockmann on ära kasutanud eesti sõnade keel-meel häälikulise kokkukõla, liites sellega teisegi riimuva sõnapaari libe-kibe:

Der wehlet di $\beta$ der ander das / sie trennen vns ohn alle Maß / vnd gleissen schön von aussen. ${ }^{3}$

\author{
Üx kihtap / töine laitap se / \\ Üx Nouw ep eal peetaxe \\ Keel libbe on / Meel kibbe. ${ }^{4}$
}

\footnotetext{
${ }^{3}$ Siinne saksakeelse versiooni kirjapilt vastab Stahli lauluraamatus avaldatule: sealses proosaversioonis on vastav salmiosa eesti keelde tõlgitud nii: se üx tahap sedda / se töine töist / nemmat lahotawat meid keickest pohlest / ninck paistwat weljaspitte kaunist (Lauluraamat 1637: 134).

${ }^{4}$ Siinne kirjapilt pärineb lauluraamatu teisest trükist (Lauluraamat 1673: 265-266), sest lauluraamatu esmatrüki digiteeritud variandis, mis on tehtud rahvusraamatukogu eksemplari järgi, vastav lehekülg (Lauluraamat 1656: 320) puudub; üldjuhul on tõlked teises trükis toodud praktiliselt muutmata kujul. Rütmist ettekujutuse saamiseks tasub meeles pidada, et diftong ea teises värsis sõnas eal loeti kahte silpi kuuluvaks.
} 
Viimast laadi tõlkepärlid on siiski harvad ning üldjuhul on värsitehniline perfektsus saavutatud keele loomulikkuse hinnaga. Värsimõõdu nõudel on näiteks üleliigsed silbid sõnadest tihti lihtsalt välja visatud. Sama võtet võib kohata ka saksa luules, kuid võoras keeles on tõlkijad end ilmselt veelgi vabamalt tundnud, käänates näiteks sõna jumal läbivalt sisekaolisena (jumla jne), et seda vahelduvasse trohheilisesse või jambilisse meetrumisse suruda. Lisaks moonutatud sõnakujudele kasutatakse ka keelele võõraid süntaktilisi konstruktsioone ja ellipseid, nii et luuletuse mõtet on enamasti raske jälgida ning vahel on see ilma originaali abita lausa võimatu.

Võib üsna kindlalt väita, et tõlkijad ei ole oma tegevuses arvestanud talupoegadest sihtgrupi suutlikkusega laulude sisu taibata, vaid nende peamiseks huviks on olnud tõestada eestikeelse silbilisrõhulise lõppriimilise luule võimalikkust ja proovile panna oma värsitehnilist meisterlikkust. See on omaenese virtuoossust imetlev, vormitäiuslik barokne luule, millel pole talupoegadest koguduseliikmete hingehooldusega kuigi palju pistmist.

Ka esimese värsistatud lauluraamatu kaasaegsed proosatekstide tõlked jäid eestikeelsele kogudusele arvatavasti üsna kaugeks, sest sealgi pöörati tähelepanu pigem teksti vormilisele meisterlikkusele, arvestamata, kas ja kuivõrd tulemus eestlaskonnale arusaadav võiks olla. Näiteks Johannes Gutslaffi lõunaeestiline piiblitõlke keel annab küll tunnistust üsna heast kohaliku murde tundmisest, kuid Gutslaff on selle elemente abstraktsetele analoogiareeglitele tuginedes nii suvaliselt omavahel kombineerinud ning klassikalistest keeltest pärit mustritega sobitanud, et tulemuseks on tehislik keelevariant, mida nii kohalikel talupoegadel kui ka Gutslaffi kolleegidel pidi olema raske jälgida. Lauluraamatu kaastõlkija Heinrich Göseken oma piiblitõlkes küll laulutõlgetele omaseid võtteid ei kasutanud, vaid kopeeris ülima täpsusega Lutheri piiblitõlke saksa keelt, nii et kolleegidele oli tema tõlge ilmselt mõistetav, kuid eesti kogudusele jäi see kaugeks.

Laulutõlked võisid eestlastele tänu ladusale vormile siiski pähe jääda, nii et oletatava kõrge maine tõttu võis esimese värsistatud lauluraamatu repertuaarist üht-teist eesti keeles juurduda, ehkki suurt muutust need eesti kogukonna keelekasutuses arvatavasti kaasa ei toonud.

\section{Eelpietistlik tõlge}

Sajandi lõpukümnenditel pääses eesti keelealal Liivimaa kindralsuperintendendi Johann Fischeri toel üha enam valitsema arusaam, et kirjakeele arendamisel tuleb lähtuda tegelikust keelekasutusest, mitte abstraktsetest analoogiale tuginevatest reeglitest, nagu seda olid teinud sajandi keskpaiga kirjakeele arendajad. Uudset suhtumist said mõistetavalt edendada ainult literaadid, kes kõneldud keelt piisavalt hästi oskasid. Fischeri vaateid asusid ellu viima noored keelereformaatorid Adrian Virginius ja Johann Hornung, kes mõlemad kohalike pastorite poegadena eesti keele juba lapsepõlves olid omandanud. Nad naeruvääristasid Eestimaa konsistooriumi barokset keelekasutust (Tafenau 2011), tõlkisid nii Vana kui ka Uut Testamenti senisest palju ladusamasse keelde ning hakkasid ka laulutõlkeid eestikeelse kogukonna tegelikele vajadustele ja võimalustele kohandama. 1690. aastatel ilmusid nii lõuna- (1690) kui ka põhjaeesti keeles (1694) uued lauluraamatud, 
milles enamik laule olid põhjalikult ümber sõnastatud. Uute tõlgete levikut pidurdas rivaalitsev Eestimaa konsistoorium, kes andis veel 1693. aastal välja oma esimese värsistatud lauluraamatu kolmanda trüki praktiliselt muutmata kujul. Kõige enam takistas revideeritud tõlgete üldisse kasutusse jõudmist aga algav Põhjasõda oma laastavate tagajärgedega. Adrian Virginiuse ja Johann Hornungi keelt on tagantjärele kõrgelt hinnatud ja ülistatud ning pole mingit kahtlust, et nende tegevus suunas kogu eesti kirjakeele arengu täiesti uude faasi, ent selle kohta, kui palju see nende kaasaegse eestlaskonna keeleteadvust mõjutas, on raske midagi kindlamat väita.

\section{Pietistlik tõlge}

Nõnda võib esimeseks uut tüüpi lauluraamatuks, mis rahva seas tõesti levis ja terve eesti kogukonna keeleteadvuses midagi oluliselt muutis, pidada pietistide 1721. aasta lauluraamatut. Sellest anti välja palju trükke, alates 1740 . aastast koos hernhuutlikke laule sisaldava lisaga (vt allpool), ja see oli kasutusel ligi poolteist sajandit. Uuem lauluraamatu versioon tuli käibele alles 1869 ning päris uus valmis XIX sajandi lõpuks (Sissejuhatus 1909 [1899]). Kirikulaulud mõjutasid eestlaste mentaliteeti tervikuna (Paul 2002) ning muutsid eesti keeleteadvust.

Lauluraamatu andis välja põhimõtteliselt sama seltskond, kes seisab ka esimese eestikeelse piiblitõlke taga. Puhtkeeleliselt on lauluraamat ja piiblitõlge üsna sarnased. Üldjoontes tuginesid pietistid sajandilõpu keeleuuendajate loodud põhjaeesti kirjakeelele ning järgisid oma keelearenduses neidsamu hoiakuid, millega kirjakeele kujundamisel oli analoogiale toetuvate ratsionaalsete keelereeglite asemel otsustavaks kuulutatud tegelik keelekasutus. Ka pietistide jaoks oli oluline väljenduda võimalikult rahvapäraselt. Murdeliselt baasilt tugineb pietistide keel eeskätt põhjaeesti keskmurdele, ilmutades - tõenäoliselt Vestringi vahepealse panuse mõjul - veidi enam läänemurdelisi jooni kui idamurde alalt pärit Hornungi tõlked (Saareste 1940: 29-45; Kask 1984: 88-95). Ka paistab pietistide keel silma varasemast rangema normeerituse poolest, ehkki selles osas on ühelt poolt käsikirja jäänud piiblitõlkeid ja hoolikalt toimetatud trükiteksti, teisalt vormisundusele allutatud laulutõlget ja proosateksti muidugi raske võrrelda. Siiski võib kokkuvõtvalt väita, et pietistide lauluraamatus ja piiblitõlkes on lingvistilises lõikes tegemist ühe ja sama allkeelega, mis on sajandi lõpu keeleuuendajate tegevuse otsene edasiarendus.

Ka pietistide piibli ja lauluraamatu tõlkelugu on väliselt omavahel sarnased. Piiblis võeti ühe osa (Uue Testamendi) aluseks vana tõlge, mida keeleliselt toimetati, teine osa (Vana Testament) tõlgiti uuesti, kusjuures tõlkijateks oli tosinkond pastorit, aga tõlke toimetas ja ühtlustas väike tuumik, keda juhtis Anton Thor Helle. Rudolf Põldmäe andmetel olid lauluraamatu tõlkijad või vähemalt toimetajad enam-vähem samad inimesed, kes hiljem moodustasid ka esimese eestikeelse trükipiibli väljaandjate tuumiku. Lauluraamat ilmus kolmanda osana kiriku käsiraamatust, mille väljaandjateks valiti 1720 . aastal Heinrich Gutsleff Kullamaalt, Johann Middendorff Keilast, Hermann Johann Heitzig Koselt ja A. Thor Helle Jürist (Põldmäe 1939: 46). Ka lauluraamatusse võeti sisse peaaegu kõik 1694. aasta lauluraamatu tõlked (täpsemalt 117 
laulu), millele lisati 139 uut laulu (Sissejuhatus 1909 [1899]: VII), kasutades sealjuures ka teiste kaasaegsete pastorite laulutõlkeid (Põldmäe 1939: 46).

Nii piibli kui ka laulude tõlkimisel lähtuti Halle pietistide kõige uuematest arusaamadest, kuid vaatamata sellele või õigemini just selle tõttu on pietistide piiblitõlge ja laulutõlked tõlketehniliselt täiesti erinevad nähtused. Piiblitõlke osas oli saksa keeleruumis alates Lutheri tõlkest peetud enesestmõistetavaks tõlke suveräänsust. Lutheri piiblitõlge oli väärtus omaette, mille kohatist originaaltekstist kõrvalekaldumist küll üha enam teadvustati, kuid polnud seni söandatud kritiseerida. Pietistide käsitluses sai algtekst tõlkest olulisemaks, Lutheri tõlget hakati revideerima ja kommenteerima ning tekkis ka täiesti uusi saksa tõlkeid (Köster 2011). Ka Eesti piiblitõlkijad pöörasid Halle pietistide eeskujul suurt tähelepanu originaali täpsele edasiandmisele. Igale lähtesõnale püüti leida võimalikult adekvaatne eesti vaste, edastades ühte sõna mitmesõnalise väljendiga, kui muud moodi ei õnnestunud selle kõiki tähendusvarjundeid edasi anda. Originaalteksti tõlgendamisel toetuti sealjuures kõige uuematele pietistlikele allikatele (vt lähemalt Ross 1995). Piiblitõlkes ei olnud võimalik teha mingeid sisulisi hinnaalandusi ega lihtsustusi. Muidugi püüdsid pietistlikud tõlkijad eesti keele väljendusvõimalustega jõudu mööda arvestada, kuid oma tõlkemetoodiliselt põhialuselt kujunes eesti tõlge hoopis teistsuguseks, kui oli olnud kaks sajandit varasem Lutheri saksa tõlge. Originaali tähendusnüansside võimalikult täpse edasiandmise sunnil ei tulnud kõne allagi võimalus talupoegadest sihtgrupi võib-olla küsitavale taipamisvõimele mingeid järeleandmisi teha.

Lauludega oli lugu teisiti. Siingi juhinduti vanade tõlgete parandamisel pietismi õpetussuunast ja tõsteti uute laulude sissevõtmise või endiste väljajätmisega esile just Halle pietistide uudset laululoomingut (Põldmäe 1939: 46), kuid tõlketehniliselt toimiti hoopis teisiti kui piibli tõlkimisel, sest vaatamata koguduselaulu olulisusele kogu reformeeritud kirikus ei olnud laulude originaaltekstidel piibliga ligilähedaseltki võrreldavat staatust. Laulude tõlkimisel sai keskenduda põhilise sisu edasiandmisele ning vajadusel vastu tulla eestikeelse kogukonna oletatavale vaimsele suutlikkusele.

Vormiliselt üritavad pietistid enam-vähem sama täpselt jälgida silbilisrõhulist jambi või trohheust, nagu see 1656 tarvitusele võeti. Ka lõppriimi kasutavad nad järjekindlalt, ehkki nende riimid tunduvad olevat lohisevamad ning paistavad sagedamini kui esimeses värsstõlkes piirduvat kaasrõhulise silbi (või sõnaosa) vokaali(de) kokkukõlaga. Erinevalt oma baroksetest eelkäijatest eelistavad pietistid vaimukatele ja leidlikele riimidele pigem loomulikumat keelt. Varasemate tõlgetega võrreldes tuleb pietistliku tõlke omapära esile eriti selgesti kujundikeeles.

Kujundlik lihtsustamine. Loomulikuma keele taotlus iseenesest on kindlasti üks põhjusi, miks pietistide tõlge mõjub argisema ja üksluisemana kui eelkäijate sädelev barokk. Ometi tundub, et lisaks tehislike keeleliste konstruktsioonide vältimisele on pietistid täiesti teadlikult vältinud ka liialt literatuurseid kujundeid, mis võinuksid ehk jääda talurahvale arusaamatuks. Sellisele mõttele viib juba lauluraamatu avapala, milleks on Paul Gerhardti „Wie soll ich dich empfangen”. Sissejuhatava advendilauluna ei ole see mingi juhuslik näide, vaid pidi raamatu kasutajale tõesti midagi ütlema. Siinses kontekstis on eriti kõnekas avalaulu teise salmi esimese poole tõlge: 
Dein Zion streut dir Palmen

und grüne Zweige hin, und ich will dir in Psalmen ermuntern meinen Sinn. ${ }^{5}$
So koggodus sind kidab, Ning tännab röömsaste. Mo südda lauldes näitab Ka ennast wapraste. ${ }^{6}$

Originaalis viidatakse Jeesuse võidukale Jeruusalemma sisenemisele (Mt 21: 1-9), kasutades Siioni ja haljaste okste laialilaotamise kujundeid ning kõneldakse psalmide laulmisest. Eesti tõlkes on kõik literatuursed vihjed kõrvale jäetud: Siion on tõlgitud lihtsalt sinu kogudus ning teksti tähendus on selge ka ilma spetsiifilisele piiblikohale viitavate seosteta.

Esmapilgul võiks arvata, et tegemist on lihtsalt kehva tõlkega. Tänapäevastele luuletõlke standarditele see ilmselgelt ei vasta. Mõned muud näited sunnivad siiski oletama, et küsimus pole mitte tõlkijate suutmatuses originaali paremini edasi anda, vaid täiesti teadlikus kujundlikus lihtsustamises. Nii tunduvad ülejäänud tekstist silmatorkavalt paremad olevat need lõigud, mida võiks liigitada loodusluuleks. Näiteks teise Paul Gerhardti laulu „Geh aus, mein Hertz, und suche freud" teise ja kolmanda salmi tõlget (Lauluraamat 1727: 181-182) originaaliga kõrvutades võib oletada, et see, mida tõlkes vältida ja välja filtreerida on püütud, on justnimelt literatuursus, samal ajal kui talupojast lugejale või lauljale mõistetavaid looduspilte on edasi antud märksa nüansirikkamalt, vahel lausa rohkemate detailidega kui originaalis:

2. Die bäume stehen voller laub /

Das erdreich decket seinen Staub

Mit einem grünen kleide;

Narcissus und die Tulipan,

Die ziehen sich viel schöner an /

Als Salomonis seyde.

3. Die lerche schwingt sich in die luft /

Das täublein fleugt aus seiner kluft

und macht sich in die wälder.

Die hochbegabte nachtigal

Ergötzt und füllt mit ihrem schall

Berg / hügel / thal und felder. ${ }^{7}$
Mets paksust lehte la-utab, Ma ruttust rohto körkistab, On keikil' kaunis nähha, Keik lillikessed öitsewad, Ja kaunikessed kaswawad; Ni wottab Jummal tehha.

Keik linnud pessetellewad Ja omma laulo aiawad, Ja Loja kita püüdwad: Ja öpitk, käggi, leoke, Jo tu-ike, jo warblane, Et metsad wastohüüdwad.

Teise salmi tõlkest on kaotatud originaali viide Ülemlaulule (Salomonis seyde 'Saalomoni siid') ja välditakse võõrapäraseid taimenimesid (Narcissus, Tulipan $^{8}$ ), kasutades samas oskuslikult eesti omafraseoloogiat (lehte laotama 'lehte minema'9). Seevastu kolmandas salmis on originaali kolme linnu (lerche, täublein, nachtigal) vastena tõlkesse sisse toodud koguni viis talupojale

${ }^{5} \mathrm{https} / / /$ de.wikipedia.org/wiki/Wie_soll_ich_dich_empfangen

${ }^{6}$ Pietistliku lauluraamatu näited esitatakse siinses artiklis veidi hilisema trüki järgi (toodud näide Lauluraamat 1727: 3).

${ }^{7} \mathrm{https} / / /$ de.wikipedia.org/wiki/Geh_aus,_mein_Herz,_und_suche_Freud

${ }^{8}$ Nartsissi ja tulbi kujund võib ka saksakeelsetes variantides olla asendatud millegi üldisemaga, vrd http://www.hymnary.org/hymn/GEKG1908/page/389.

${ }^{9}$ Väljendit lehte laotama võib vähemalt Wiedemanni sõnaraamatu järgi pidada ehedaks eesti omafraseoloogiaks: lehti lautama 'sich belauben' (Wiedemann 1973 [1893]: vg 480, sub leht). 
tuttavat lindu: ööbik, kägu, lõoke, tuvi ja varblane. Originaalist rikkalikuma objektide hulgaga luuletõlge on igal juhul tähelepanuväärne.

Sama tendentsi võib täheldada ka näiteks Laurentius Laurenti laulu „Es sind schon die letzten Zeiten” viienda salmi esimese poole tõlkes (Lauluraamat 1727: 10):

Weil der feigenbaum ausschläget, Und anlegt sein hoffnungs-kleid, So wei $\beta$ man, da $\beta$ sich erreget

Die erwünschte sommers-zeit; ${ }^{10}$
Wigi puud, kui pakkatawad, Lähwad hire körwule, Siis keik innimessed moistwad, Et sui polle kaugele;

Tõlkest on kaduma läinud originaali lootuse-rüü kujund, kuid see-eest kasutatakse mujal tollases kirjakeeles tundmatut ja seetõttu lausa üllatavalt rahvapärasena mõjuvat väljendit hiirekõrvule minema.

Literatuursed stereotüüpväljendid. Üldisele kujundlikule lihtsustamisele vaatamata toodi kirikulauludega eesti keelde hulgaliselt teatud laadi literatuurseid metafoore. Kirikulaulude kujundikeel on kitsas, aga väga intensiivne. Eriti palju on selles tundeelu ja vaimseid kõhklusi ning otsinguid väljendavat metafoorikat. Sellealast fraseoloogiat eesti keeles arvatavasti enne XVII sajandit eriti ei olnud. Enamasti ei imporditud fraseoloogiat lauludes mitte otsetõlkena konkreetsest originaallaulust konkreetsesse tõlkesse, vaid pigem kujunesid tõlkijatel saksa lauluvara baasil välja oma meelisväljendid, mis eesti keeles meetrumisse sobisid ja mida siis tõlkimisel kasutati, ehkki originaalis ei pruukinud need konkreetses laulus üldse esile tulla. Selles mõttes võib kirikulaulu keelt pidada samasuguseks stereotüüpsete vormelite keeleks nagu suulise rahvalaulu keelt (vrd Saarlo 2005: 9-48).

Suur osa kirikulaulude korduvatest vormelitest on selgelt saksalaenulised. Kõige enam torkab silma tohutu hulk kujundeid sõnaga süda. Tegemist on vana piiblikujundiga, kuid eespool käsitletud põhjusil võib arvata, et eesti üldkeelde on selle kinnistanud kirikulaulude tõlked, kusjuures eriti intensiivselt kasutatakse seda ootuspäraselt just pietistlikus tõlkes. Kui esimeses värsistatud lauluraamatus (mis üldmahult pietistlikule õige vähe alla jääb), esineb sõna süda 210 korda, siis pietistlikus lauluraamatus tarvitatakse seda juba 439 korda, mis teeb selle kogu raamatu sageduselt neljandaks nimisõnaks (sõnade jumal, Jeesus, arm järel). Võrdluseks tasub mainida, et enam-vähem samasuguse mahuga regilaulukorpuses esineb sõna süda 30 korda, kusjuures neistki moodustavad suure osa juhud, kus sõna tähistab konkreetset organit, paralleelfraasis kopsude ja maksa või mõne muu kehaosaga (vt lähemalt Ross 2016b). Kirikulaulus tähistab süda inimese emotsionaalset või hingelist keset. Sõna esineb enamasti kas nimetavas käändes subjektina (süda nutab, lõhkeb, katkeb, valutab, valvab, näeb) või osastavas käändes objektina (miski vaevab, valgustab, puhastab, kosutab, rõ̃mustab, parandab ... südant; keegi annab oma südant [jumalale]); sage on ka elatiivne viisimäärus (südamest, kõigest südamest, rõ̃msast südamest). Südame-väljendite kõrval kohtab muidki püsiühendeid, mis võeti kasutusele juba varasemates lauluraamatutes ning said pietistide tõlkes eriti populaarseks, nagu muret kandma (üle 30 korra) jmt.

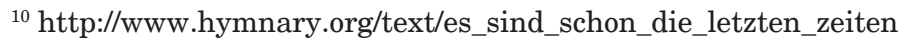


Suure rühma moodustavad maise elu kaduvust rõhutavad piiblikujundid suits(ukene), tuul, aur, lillekene, õiekene, rohi, hein, leht. Neidki võib pidada kirikulaulude keele stereotüüpkujundeiks, mida võidakse küll otse tõlkida, aga vajadusel ka üksteisega asendada, nagu on tehtud näiteks Paul Gerhardti laulu „Herr, alles Weisheit Quell” neljandas salmis (Lauluraamat 1727: 218), kus originaali sõnale Lüftlein vastab tõlkes kolm stereotüüpset elu hapruse kujundit tuul, aur ja suitsuke:

Mein Leben ist gar kurz und schwach

Ein Lüftlein, das bald lässet nach. ${ }^{11}$
Mo ello aeg on lühhike üks tuul ja aur ja suitsoke.

Või Gottfried Wilhelm Saceri laulu „Komm, Sterblicher, betrachte mich” seitsmenda salmi tõlkes (Lauluraamat 1727: 256), kus originaali kujundite pikka ritta on tõlkes lisatud ka üldiselt veidi harvemad lumi ja meevaha:

Dein Leben ist ein Rauch und $\underline{\text { Schaum, }}$ Ein Dunst und schwanker Schatten, Ein leichter Wind, ein leerer Traum, Ein Gras auf dürren Matten. ${ }^{12}$
So ello on kui suits ja waht, Kui lummi, leht, mee-wahha, Kui warri, hein ja kuiwnud roht, Mis nidetakse mahha.

Sealjuures on (mee)vaha psalmidestki tuntud kujund muutlikkuse ja hajuvuse väljendajana (Ps 22: 15, 68: 3, 97: 5); lumi aga kannab psalmides ja prohvetite raamatutes pigem puhtuse tähendust (nt Ps 51: 9, Js 1: 18). Vajaks lähemat uurimist, kas lumi esineb kaduvuse kujundina ka saksa kirikulauludes või on see siinkohal pietistlike tõlkijate poolne laiendus kõnetamaks kohalikku sihtgruppi.

Paarissõnad. Omapärase stereotüüpse rühma moodustavad kirikulaulude sageli algriimilised paariskujundid, nagu suu ja süda, meel ja mõte ( mõistus), luu ja liha, hing ja ihu jmt, või lõppriimiline keel ja meel. Nende algupära on keeruline üheselt määratleda. Mõne paari näol on tegemist saksa (ja kaugemategi eeskujukeelte) piibli- või laulukeele väljendi täpse ülekandega, mis lihtsalt kõlab eesti keeles hästi. Näiteks hing ja ihu on piiblikeelest pärit sõnapaar, mis üheski eeskujukeeles märkimisväärset kokkukõla ei ilmuta vrd hbr néfeš / basár (nt Js 10: 18), kr psyhē / sōma (nt Mt 10: 28), lad anima / corpus, sks Seele / Leib -, aga eesti keeles juba piibli proosatekstide tõlkes (eriti põhjaeesti variandis) paratamatult palju paremini kõlas: nt Mt 10: 28 Kartge agga sedda, ke Jhho n. hinge rikkuda woib Pörgo tulles (Müncheni käsikiri 1694). Otsetõlkelisena esineb sõnapaar muidugi ka Stahli kirikulauludes, kus see kohmaka sõnastuse tõttu siiski veel ladusa vormelina ei mõju. Ent alates 1656. aasta tõlkest on hing ja ihu saksa Leib und Seele kinnisvasteks, millega mõnikord tõlgitakse ka saksa alliteratiivset väljendit Leib und Leben. Pietistlikus lauluraamatus esineb sõnapaar hing ja ihu ühes värsis kokku 34 korral (neist paaril juhul küll pikema loendi osana, kuid enamasti selge paarisväljendina). Päritolu mõttes kehtib sama ka väljendi luu ja liha kohta, mis pole aga pietistlikes lauludes nii sage.

Algriimiline väljend suu ja süda on pietistlikes uustõlgetes peaaegu alati otseülekanne saksa lähtekujundist Mund ( Zung) und Herz. Samas esineb

\footnotetext{
${ }^{11} \mathrm{http}: / /$ www.hymnary.org/text/herr_alle_weisheit_quell_und_grund

${ }^{12} \mathrm{http} / / / \mathrm{www}$. hymnary.org/text/komm_sterblicher_betrachte_mich
} 
see juba 1656. aasta barokktõlkes, kus Georg Salemann on seda kasutanud vaba tõlkelise fraseologismina Nicolaus Selnecceri laulu „Singen wir aus Herzensgrund" avarea tõlkes: Nühdt laulkem Suhst ninck Süddamest (Lauluraamat 1656: 129). Selle ilusa tõlke on pietistid muidugi säilitanud. Kokku esineb väljend pietistlikus tõlkes selge paarisväljendina kuus korda ning lisaks hajusamal kujul veel kaheksa korda.

Samuti algriimiline paarisväljend meel ja mõte ( mõistus) paistab aga olevat XVII sajandi lõpu keelereformaatorite laulutõlgetesse toodud spetsiifiline eesti tõlkekeelend, mille pietistlikud tõlkijad üle võtsid ja oma uutes tõlgetes võimsalt juurutasid. ${ }^{13}$ Sõnapaari on perikoobitõlgetes kasutanud kahel korral (Lk 10: 27, Mt 22: 37) õieti juba Joachim Rossihnius (1898 [1632]: 135, 142), ehkki tollastele tõlgetele lähtetekstiks olnud Lutheri tõlkes on vastava keelendi lähe ühesõnaline (Gemüt). Sõnapaaril puudubki selge saksa lähe. Sama paariskujund esineb ka pietistide piiblitõlkes Õp 1: 4 Et ta annaks ... noortele head meelt ja möttet (Piibel 1739: 629), kus see on vasteks heebrea väljendile dáat u-mezimá ja kus selle alliteratiivsus võib olla inspireeritud Lutheri tõlkevastest vernünftig und vorsichtig. XVII sajandi lõpu keeleuuendajate tõlkes esineb paarisväljend meel ja mõte kolm korda (Lauluraamat 1694), kusjuures saksa lähtetekstis võivad vastavas salmis esineda erinevad sõnad (Herz und Gedanken, Sinnen und Verstand). Pietistlikus lauluraamatus on eelmise sajandi lõpu tõlgete vasted säilitatud ning sama sõnapaari kasutatakse ohtralt uutes tõlgetes saksa originaaltekstist täiesti sõltumatult. Kokku esineb väljend meel ja mõte pietistlikus lauluraamatus 21 korda (enamasti selge sõnapaarina, vahel hajusamalt ühe värsi piires), lisaks kaks korda meel ja mõistus. Rossihniuse kasutus ning mõned lähedased tarvitused teistes vanades tõlgetes kinnitavad, et tegemist on varases vaimulikus tõlkekirjanduses tuntud väljendiga. Väljendi jõuline esindatus pietistlikes laulutõlgetes võib olla siiski analoogia mõjul inspireeritud ka saksa kirikulaulude eeskujust, ehkki otsene saksa lähe puudub. Seesuguseid alliteratiivseid sõnapaare kasutas sageli pietistliku lauluraamatu uute laulude põhiautoreid Paul Gerhardt, keda on nimetatud lausa alliteratsiooni, tähenduslikult seotud sõnade kõlalise seostamise ja muude kokkukõlade meistriks (Gabriel 1957: 28).

Samas võis pietistlikele tõlkijaile eeskuju pakkuda ka eesti rahvakeel. Pole küll otseseid andmeid selle kohta, et nad tundnuksid regivärsilise rahvalaulu keelt, kuid alliteratiivsete paarisväljenditega võisid nad kokku puutuda ka argikõnekeelse fraseoloogia vahendusel. Igatahes esineb nende tõlkes alliteratiivseid paarisväljendeid, mis näivad olevat võetud otse eesti rahvapärasest keelekasutusest, nagu põrm ja pihu, mäed ja mättad, tuld ja tõrva.$^{14}$ Erinevalt

${ }^{13}$ 1656. aasta tõlkes kasutab Martin Gilläus laulu „Der Tag vertreibt die finstre Nacht” kuuenda salmi tõlkes (Lauluraamat 1656: 95) problemaatilist väljendit Oh Innimenn' sa kallis Lohdt / Kel andtut Jumlast Meelt ninck Möhdt (vrd orig http://www.hymnary.org/text/ der_tag_vertreibt_die_finstre_nacht), milles sõnakuju Möhdt tuleks vist pigem tõlgendada sõna mõot vormina. Igatahes on kolmandast trükist (Lauluraamat 1693: 84) paarisväljend eemaldatud ja kogu eestinduse sõnastust muudetud (Oh Innimenn'/sa kallis Töh/Sull' terwe Mehl/ett möttele) ning siin vaadeldav eesti paarisväljend võetakse selles salmis kasutusele alles pietistlikus tõlkes: Oh innimenne! mötle sa, Et sul on meel ning moistus ka (Lauluraamat 1727: 282).

${ }^{14}$ Loetletuist esimest kasutavad pietistid ka piiblitõlkes, kus sellel on ühel juhul olemas koguni alliteratiivne heebrea lähtepaar (5Ms 28: 24 'avak ve-'afar) ning see kajastub ka Anton Thor Helle grammatikale lisatud sõnastikus (pihho ja pörmo). 
kirikulaulude allkeele literatuurse tagapõhja või tekkelooga sterotüüpvormelitest hing ja ihu, suu ja süda, meel ja mõte esinevad nood rahvakeelseina mõjuvad paarisväljendid igaüks ainult üks kord.

Lõppriimilise sõnapaari keel ja meel tõid eesti silbilisrõhulisse ja lõppriimilisse luulesse juba baroksed tõlkijad, nagu nähtus ka eespool eesti barokse luuletõlke tipuks kuulutatud Reiner Brockmanni eestindusest Keel libbe on/Meel kibbe. Brockmann ja Gilläus kasutavad Lutheri laulu „Vater unser im Himmelreich" esimese salmi ühistõlkes sama sõnapaari ka värsilõpu riimina: Och aita / et ep üxnes Keel / Waid palluko kahs Hing ninck Meel. Värsi lõppriimina kasutavad seda sõnapaari ohtrasti ka pietistlikud tõlkijad, harvem värsisiseses loendis.

\section{Pietistlik laulukeel ja ärkamisaegne luule}

Saksa originaallaulude kujundeid lihtsustades ning stereotüüpseid literatuurseid väljendeid rahvakeelsetega põimides loodi pietistlikes tõlgetes omaette allkeel. See oli peamiselt talupoegadest koosnevale publikule mõistetavam kui muud kirikukeele variandid. Ladusate laulude kaudu, mida pähe õpiti ja üheskoos kirikus lauldi, juurdus see jõudsasti, saades XIX sajandiks eesti keeleteadvuse lahutamatuks osaks.

Eesti kultuuriloos rõhutatakse kirjaoskuse ja üldse kirjasõna levimisel eeskätt hernhuutluse osa, vastandades seda kaasaegsele pietistlikule ametlikule kirikule (nt Põldmäe 1965: 207-209). Sisuliselt on hernhuutluse suhteid pietismi ja n-ö ortodoksse luterliku kirikuga Saksamaal ja Eestis kirjeldanud Voldemar Ilja (1995: 205-229). Lingvistiliselt ja värsitehniliselt kuuluvad hernhuutlikud laulutõlked pietistlikega kokku, olles lihtsalt mõnevõrra hilisemad. Alates pietistliku lauluraamatu 1740. aasta trükist liideti senistele tõlgetele 103 vennastekoguduse laulust koosnev lisa „Monned Kaunid Waimolikud Laulud" (ER 2000: 188), ent kuni 1860. aastatel valminud lauluraamatu uuema versioonini jäid need hernhuutlikud laulud lauluraamatu põhiosast eraldi ning vennastekoguduse laule ilmus ka eraldi kogumikena. Rudolf Põldmäe on hernhuutlike laulude kohta täheldanud, et nende tõlgetes lihtsustati „elegantset barokset luulet” nii kujundlikult kui ka keeleliselt, selleks et kohandada laule „eesti talupoja lihtsa arusaamise jaoks” (Põldmäe 2011: 155-156). Siinse vaatluse põhjal tohib arvata, et laulude teadliku lihtsustamise ja „talupoja lihtsa arusaamise jaoks” kohandamise võtsid ette juba esimesed pietistlikud tõlkijad. Eesti kogukonna ettevalmistamisel kirjakultuurist osasaamisele, mis sai teoks XIX sajandi rahvusliku ärkamise käigus, oli pietistlikul lauluraamatul (koos selle hilisema hernhuutliku lisaga) igatahes oluline roll.

Kirikulauludega eesti keelde kinnistatud kujundisüsteemile projitseerus kogu XIX sajandi ärkamisaja luule, nagu kenasti illustreerib kas või Johann Heermanni populaarse laulu „Herzliebster Jesu, was hast du verbrochen” 12. salmi pietistliku tõlke ${ }^{15}$ ja Lydia Koidula luuletuse „Mu isamaa on minu arm" alguse kõrvutus:

${ }^{15}$ Heermanni laul pärineb aastast 1630 ja ilmus eesti keeles esimest korda juba 1656 . aasta barokses tõlkes. Originaalis ja barokiaegses tõlkes 12. salmis südame kujundit pole, teistes salmides tuleb süda kõneks küll, kuid mitte väljendis südand andma (vt http://www. hymnary.org/text/herzliebster_jesu_was_hast_du_verbrochen). 
So heldust tahhan minna meles kanda, Ja sulle üksi minno süddant anda,

(Lauluraamat 1727: 58-59)
Mo isamaa on minno arm /

Kel südant annud ma,

(Koidula 1969 [1867]: 103)

Siin pietistide väljaande järgi tsiteeritud tõlkeversioon pärineb tegelikult XVII sajandi lõpu keeleuuendajatelt ja ilmus esmakordselt 1694. aasta lauluraamatus (Lauluraamat 1694: 28). Pietistide lauluraamatuga kandus see XIX sajandi teise poolde ning oli kasutusel ka 1867. aastal, mil ilmus Koidula luuletus. Kahe eestikeelse teksti vahe on niisiis rohkem kui 170 aastat, aga nende kujundikeel on kattuv. Muutunud on ainult see, kellele südant antakse: kirikulaulus jumalale, ärkamisaegses rahvusromantilises luuletuses isamaale.

Omaette küsimuseks jääb, kust tasub otsida ärkamisaegse luule a u t o r i t e keele lätteid: kas eesti kirikulaulust või pigem kaasaegsest saksa romantilisest luulest (mille kujundikeelt olid muidugi mõjutanud needsamad saksa kirikulaulude originaalid, millest eesti kirikulauludki lähtusid). Selle selgitamiseks tuleks täpsemalt kõrvutada lisaks saksa kirikulaulude ja eesti pietistlike ning hernhuutlike tõlgete keelele ka XIX sajandi romantilise saksa luule ja eesti ärkamisaegse luule kujundikeelt. Eriti intrigeeriv on see küsimus kahtlemata Koidula puhul, kelle trotsliku isamaaluule suhted pastorist isa alalhoidlikkuse ning saksakeelse kodu ja kasvatusega on kõigi biograafide ja uurijate tähelepanu köitnud. ${ }^{16}$ „Mu isamaa on minu arm” peaks olema ilma selge saksa eeskujuta originaalluuletus, nii et Koidula eesti keeles pidi kujund südant andma igatahes olemas olema.

Aga kui XIX sajandi ärkamisaegsete eesti l u u l e t aj a t e kohta ongi esialgu raske öelda, kas nad laenasid oma kujundid kaasaegsest saksa luulest või olid suure osa neist omaks võtnud juba eestikeelsetest kirikulauludest, siis eesti ärkamisaegse luule lu g ej a jaoks tulevad pinnase ettevalmistajana kõne alla ainult needsamad pietistlikud kirikulaulud. Just kiriku lauluraamat andis eesti kogudusele keele, millega XIX sajandi ärkamisaegne rahvusromantiline luule tema poole pöördus. Tänu kirikulauludele olid eestlased kogukonnana jõudnud kirjakultuurile lähemale, kui see ilma omakeelse vaimse eliidita rahva korral üksnes katekismuse ja piiblitõlke toel võimalikuks oleks osutunud. Lauluraamatu n-ö eelsoojenduseta poleks lugejaskond ärkamisaegset luulet nii jäägitult omaks võtnud.

\section{Kokkuvõtteks}

Eesti filoloogia kasvas välja saksa emakeelega pastorite praktilisest vajadusest suhelda eesti kogukonnaga. See tekkis saksakeelse distsipliinina, mis huvitus XVII-XIX sajandini eesti keelest ja selles viljeldud rahvaluulest. Eestikeelne ehk sisevaateline eesti filoloogia sai sündida alles rahvusromantilise ilukirjanduse ja selle üle arutleva kirjanduskriitika tekkides. Viimase eelduseks oli eesti kirjakeele jõudmine arengujärku, kus see suudaks vahendada nõudli-

${ }^{16}$ Kristlikud palvetunnid, mida Johann Voldemar Jannsen perele pidas ja kus „koraale lauldi ja testamendi lugusid loeti”, olid Aino Kallase käsitluse kohaselt saksakeelsed (Kallas 1918: 32, 37). Madli Puhvel, kes näib olevat oma raamatus ära maininud kõik tähelepanekud, mis Koidula keelekasutuse kohta on teada, väidab hilisemate uuringute valgel siiski, et vähemalt Vändra-päevil pidi Jannsenite kodu olema veel kakskeelne (Puhvel 1995: 22-23). 
kumaid poeetilisi taotlusi, olles samas jõukohane ja arusaadav piisavalt suurele osale eestikeelsest kogukonnast.

Saksa pastorid lõid eesti kirjakeele katekismuste, kirikulaulude ja perikoopide tõlkimise käigus, et varustada viletsama keeleoskusega kolleege eestikeelsete jutluste läbiviimiseks ja eestlaste hingehoolduseks hädavajaliku materjaliga. Varaprotestantlikud tõlked sündisid pragmaatilistest teoloogilistest kaalutlustest. Üksikutes tõlkefragmentides võib oletada püüdu eestikeelsele kogukonnale mõistetavaks osutuda, kuid üldiselt olid nende otseseks sihtrühmaks viletsama keeleoskusega saksa pastorid ning keele väljendusrikkuse arendamisega polnud tollastel tõlkijatel mahti tegelda. Poeetilised taotlused tõusevad võimsalt esiplaanile barokiaegsetes tõlgetes. Nii Johannes Gutslaffi piiblitõlke kui ka esimese värsistatud lauluraamatu keelt ilmestab vormilise täiustamise püüe, mille ajel keel allutatakse võõraste analoogiate eeskujule. Barokktõlge lõi keeruliste vorminõuetega kirjakeele, mis jäi oma tehislikkuses eestikeelsele kogukonnale kaugeks, ehkki rütmiliselt ladusad ja heakõlalised kirikulaulud võisid talupoegadest koguduseliikmetele pähe jääda. Pööre kirjakeele ja selle loomuliku kandepinna, emakeelsete eestlaste suhetes toimus XVII sajandi lõpul, mil kirjakeele arendamisel hakati rohkem arvestama reaalse keelekasutusega ning tõlgete eestikeelse sihtrühma vajadustega. Põhjasõja tingimustes ei saanud toonased tõlked kuigivõrd levida ning algatatud muudatust jätkasid ja uue allkeele arendasid välja pietistid. Piiblikeeles polnud neil võimalik minna lihtsustamise teed, kuid oma 1721 . aasta lauluraamatus on nad ilmselgelt maksnud mõistetavuse huvides lõivu laulude potentsiaalse tarvitajaskonna vaimsele horisondile. Laulude kujundikeelt on teadlikult lihtsustatud ja harimatule rahvale kohandatud, rikastades seda samal ajal üksikute rahvakeelsete väljenditega. Ühtlasi tõid pietistid oma laulutõlgetega eesti keeles käibele teatud laadi literatuursed kujundid, millest osa oli leidnud kasutamist juba varasemates laulutõlgetes, kuid sai nüüd uute, paremini mõistetavate tekstide osana võimaluse üldkeeles kinnistuda. Nõnda lõi pietistide laulukeel pinnase eesti filoloogia sisevaate tekkimiseks.

Kirjutise valmimist on toetanud Euroopa Liit Euroopa Regionaalarengu Fondi kaudu (Eesti-uuringute tippkeskus), see on seotud Eesti Haridus- ja Teadusministeeriumi uurimisprojektiga PUT-550 „Kultuurinihe eesti keeles 17./18. sajandil”.

\section{Allikad}

Koidula, Lydia 1969 [1867]. Luuletused. Tekstikriitiline väljaanne. Koost Eeva Aaver. Eesti NSV Teaduste Akadeemia Fr. R. Kreutzwaldi nimeline Kirjandusmuuseum. Tallinn: Eesti Raamat.

Lauluraamat 1637 = Hand- und Hauszbuches Für die Pfarherren und Hauszväter

Esthnischen Fürstenthumbs, Ander Theil, Darinnen das Gesangbuch, Zusampt den Collecten und Prefationen. Reval: Christoff Reusner der älter.

Lauluraamat $1656=$ Neu Ehstnisches Gesangbuch, Worinnen die Kirchen-Gesänge

Sel. Hn. Lutheri und anderer Gottseligen Männer in die gewöhnliche Melodeyen und gleiche Reimen verfasset sind. Reval: Adolph Simon.

Lauluraamat 1673 = Neu Eestnisches Gesangbuch / Worinnen die KirchenGesänge Sel. Hn Lutheri und anderer Gottseligen Männer in die gewöhnliche Melodeyen und gleiche Reimen verfasset sind. Reval: Adolph Simon. 
Lauluraamat 1693 = Ehsti-Ma Laulo-Rahmat / Tallo-Rahwa Kohli- nink KirkoLapsede tarbix / kud Jummala Auwux / ninda welja-sähdtut. Tallinn: Christoff Brendeken.

Lauluraamat 1694 = Ma Kele Laulo Ramat / Kummas Önsa Lutri / ja mu pühha Meeste Sure-Pühha-ha muid Ihho ning Hinge Häddas tarwiks tullejad Laulo leietakse. Riga: Johann Georg Wilcken.

Lauluraamat 1727 = Eesti-Ma-Rahwa Laulo-Ramat, mis sees Önsa Lutterusse ja muud teised wannad ning ued kaunid Laulud on üllespandud. Tallinn: J. Köler. [1721. aasta lauluraamatu 3. trükk.]

Müncheni käsikiri 1694 = Meie Issanda Iesusse Kristusse Ued Testament. [Johann Hornungi Uue Testamendi tõlkekäsikirja vanim säilinud koopia, mida hoitakse Münchenis Baieri Riigiraamatukogus (Cod.livo-esthon.1)].

Piibel 1739 = Piibli Ramat / se on keik se Jummala Sanna, mis Pühhad Jummala Mehhed / kes pühha Waimo läbbi juhhatud / Wanna Seädusse Ramatusse Ebrea Kele ja Ue Seädusse Ramatusse Kreka Kele essite on ülleskirjotanud / nüüd agga hopis / Jummala armo lääbi, meie Eesti-Ma Kele Essimest korda üllespandud, ja mitme sündsa salmiga ärraselletud. Tallinn: Jakob Joan Köler.

Rossihnius, Joachim 1898 [1632]. Südestnische Uebersetzung des Lutherischen Katechismus, der Sonntags-Evangelien und -Episteln und der Leidensgeschichte Jesu ... mit einer Einleitung von Wilhelm Reiman. (Verhandlungen der gelehrten Estnischen Gesellschaft 19.) Jurjew: H. Laakmann.

\section{Kirjandus}

ENE 1970 = Eesti nõukogude entsüklopeedia. 2. kd. E-HERM. Tallinn: Valgus. ER 2000 = Eestikeelne raamat 1525-1850. Toim Endel Annus. Eesti Akadeemiline Raamatukogu. Tallinn: TA Kirjastus.

Gabriel, Paul 1957. Geschichte des Kirchenliedes. Ein Abriß. - Handbuch zum Evangelischen Kirchengesangbuch. Hrsg. von Christhard Mahrenholz und Oskar Söhngen unter Mitarbeid von Otto Schlißke. Band II. Teil 2. Göttingen: Vendenhoeck \& Ruprecht, lk 5-44.

Habicht, Külli 2001. Eesti vanema kirjakeele leksikaalsest ja morfosüntaktilisest arengust ning Heinrich Stahli keele eripärast selle taustal. (Dissertationes philologiae Estonicae Universitatis Tartuensis 10.) Tartu: Tartu Ülikooli Kirjastus.

Ilj a, Voldemar 1995. Vennastekoguduse (herrnhutluse) ajalugu Eestimaal (PõhjaEesti) 1730-1743 (I osa). Tallinn: Logos.

Kallas, Aino 1918. Tähelend. Koidula elulugu. Tlk Friedebert Tuglas. Tartu: Odamees.

Kask, Arnold 1984. Eesti murded ja kirjakeel. (Eesti NSV Teaduste Akadeemia Emakeele Seltsi toimetised 16.) Tallinn: Valgus.

Kö s t e r, Beate 2011. Pietismus und Bibelübersetzung. - Übersetzung. Ein internationales Handbuch zur Übersetzungsforschung. Hrsg. von Harald Kittel, Armin Paul Frank, Norbert Greiner, Theo Hermans, Werner Koller, José Lambert, Fritz Paul. 3. Teilband. Berlin-Boston: Walter de Gruyter, lk 2396-2400.

Lepajõe, Marju 2009. Reiner Brockmanni värsside vältimatusest. - Keel ja Kirjandus, nr 10, lk 758-776.

Luther, Martin 2000 [1530]. Kiri tõlkimisest ja pühakute eestpalvest. Tlk Kristiina Ross. - Vikerkaar, nr 2-3, lk 83-96. 
Masing, Uku, So os a ar, Albert 1999 [1956]. Kolme sajandi eest värsistatud lauluraamatust. - Uku Masing, Eesti vanema kirjakeele lood. Tartu: Ilmamaa, lk 75-78.

Neithal, Reet 2005. Reiner Brockmannist ja eesti (tõlke)luule vanusest. - Keel ja Kirjandus, nr 2, lk 92-98.

Pa u l, Toomas 2002. Kirikulaulust, mentaliteedist ja matusekommetest. - Emakeele Seltsi aastaraamat 47 (2001). Tallinn: Eesti Teaduste Akadeemia Emakeele Selts, lk 46-62.

Plath, Ulrike 2008. „Euroopa viimased metslased”: eestlased saksa koloniaaldiskursis 1770-1870. - Rahvuskultuur ja tema teised. Toim Rein Undusk. (Collegium litterarum 22.) Tallinn: Underi ja Tuglase Kirjanduskeskus.

Puhvel, Madli 1995. Symbol of Dawn. The Life and Times of the 19th-Century Estonian Poet Lydia Koidula. Tartu: Tartu University Press.

Põldmäe, Rudolf 1939. Anton Thor Helle, esimese eesti piibli tõlkija. - Vana Tallinn IV. Tallinna Ajaloo Selts, lk 35-74.

Põld mä e, Rudolf 1965. Hernhuutlik kirjasõna XVIII sajandil ja XIX saj. algul. Eesti kirjanduse ajalugu I. Esimestest algetest XIX sajandi 40-ndate aastateni. Toim Aarne Vinkel. Tallinn: Eesti Raamat, lk 205-229.

Põldmäe, Rudolf 2011. Vennastekoguduse kirjandus. (Eesti mõttelugu 101.) Tartu: Ilmamaa.

R o s s, Kristiina 1995. Ülemlaulu tõlkest esimeses eestikeelses Piiblis. - Akadeemia, nr 1, lk 3-29.

R o s s, Kristiina 2013. Riimi sunnil sündinud elukas. - Keel ja Kirjandus, nr 1, lk $522-528$.

Ros s, Kristiina 2016a. Kirikulaulu osast eesti keele kirjalikustumisel (Ilmumas Eesti Rahvusraamatukogu toimetiste sarjas „Raamat ja aeg”.)

Ross, Kristiina 2016b. Words, forms and phrases in Estonian folksongs and hymns. (Ilmumas ajakirjas Folklore.)

Sa areste, Andrus 1940. Piibli keel ja rahvakeel. - Piibli keelest. Kahesajaaastast eestikeelset piiblit mälestades. (Akadeemilise Emakeele Seltsi toimetised XLIV.) Tartu: Akadeemilise Emakeele Seltsi Kirjastus.

S a a r l o, Liina 2005. Eesti regilaulude stereotüüpiast. Teooria, meetod ja tähendus. (Dissertationes folkloristicae Universitatis Tartuensis 5.) Tartu: Tartu Ülikooli Kirjastus.

S a le m a n n, Georg, Gös ek e n, Heinrich, Gillä u s, Martin 1656. An- und Vorrede an den günstigen Leser. - Neu Ehstnisches Gesangbuch, Worinnen die KirchenGesänge Sel. Hn. Lutheri und anderer Gottseligen Männer in die gewöhnliche Melodeyen und gleiche Reimen verfasset sind. Reval: Adolph Simon, [lk 17-36]. Sissejuhatus 1909 [1899] = Uus Lauluraamat. Kirikus, koolis ja kodus pruukida. Kolmas trükk. Tartu: K. Mattisen, lk V-X.

T a fen a u, Kai 2011. Ex ignorantia linguae ridiculus sensus. Eestikeelsete tekstide kriitikast 17. sajandi lõpul. - Lugemise kunst. Koost Piret Lotman. (Raamat ja aeg 2, Eesti Rahvusraamatukogu toimetised 13.) Tallinn: Eesti Rahvusraamatukogu, lk 123-150.

W i e d e m a n n, Ferdinand Johann 1973 [1893]. Eesti-saksa sõnaraamat. Neljas, muutmatu trükk teisest, Jakob Hurda redigeeritud väljaandest. Tallinn: Valgus.

Virginius, Adrian 1983 [1691]. Vorrede. Osmo Ikola, Vanhan etelävirolaisen käsikirjan esipuhe. - Sananjalka 25. Turku: Suomen Kielen Seura, lk 134-142. 


\section{Hymn translations and the history of Estonian philology}

Keywords: Estonian philology, figurative language, Lutheran hymns, Pietist hymnal, translation, old Literary Estonian

In the development of Estonian philology, two phases can be distinguished: the phase of the so-called external view, when the meta-language of philological discussions was German, and the phase of the internal view, when since the $19^{\text {th }}$ century, Estonian began to be used as the meta-language for speaking and writing about the Estonian language and folklore as well as about the emerging literature. The emergence of Estonian authors' literature and literary criticism presupposed a literary language expressive enough to describe the emotional life and trains of thought of the $19^{\text {th }}$ century, but at the same time familiar enough to the mostly peasant audience of Estonian texts. Literary Estonian was first developed by German pastors and up to the $19^{\text {th }}$ century most of the texts created in this variety remained unaccustomed for the Estonian target group. Hymns were the only kind of literature Estonians had had to learn by heart and actually pronounce already since the $16^{\text {th }}$ century. In the $18^{\text {th }}$ century, Pietist pastors composed a hymnary where the figurative system of the original German hymns was intentionally simplified. The variety of the Pietist hymnal combined a short list of literary figures of speech with idioms of the spoken vernacular. The hymnal became extremely popular and had a great impact on the figurative thinking of Estonians. Following the example of contemporary German poetry, the same figurative language was partly used by the first educated Estonian poets during the National Awakening in the $19^{\text {th }}$ century. The article argues that it was precisely the $18^{\text {th }}$-century Pietist hymns that had made the language familiar to the grassroots, thus providing the emerging Estonian literature with a vast audience and paving the way for the second, internal-view phase of Estonian philology.

Kristiina Ross (b. 1955), PhD, Institute of the Estonian Language, Senior Researcher, kristiina.ross@eki.ee 